\title{
Epilepsija ir COVID-19: neurologo, paciento ir nacionalinès sveikatos sistemos iššūkiai pandemijos metu
}

\author{
M. Vaišvilas* \\ A. Jasionis** \\ R. Mameniškienė** \\ *Vilniaus universitetas, \\ Medicinos fakultetas \\ **Vilniaus universitetas, \\ Neurologijos centras
}

\begin{abstract}
Santrauka. Nors dažniausiai COVID-19 pasireiškia respiracinio pobūdžio simptomais ir rečiau pasitaikančiu daugybiniu organų nepakankamumu, infekuotiems asmenims galimi ir ịvairūs neurologiniai simptomai. Publikuoti COVID-19 sukeltų traukulių atvejai, nors jų sąsaja su epilepsija - abejotina. Sergančiam epilepsija asmeniui, užsikrėtus COVID-19 ir taikant gydymą priešvirusiniais vaistais, svarbi jų sąveika su vartojamais vaistais nuo epilepsijos. Psichologinė pacientu būsena taip pat yra svarbus veiksnys priepuolių kontrolei, o pandemija keičia lètinėmis ligomis sergančiųjų priežiūrą. Šiame straipsnyje pateikiame literatūros apžvalgą apie simptominių traukulių, epilepsinès būklès gydymą, taip pat epilepsija sergančių asmenų priežiūrą COVID-19 pandemijos metu. Pateikiame naujausias rekomendacijas elektroencefalografijos tyrimui atlikti.
\end{abstract}

Raktažodžiai: epilepsija, traukuliai, COVID-19, SARS-CoV-2, telemedicina, vaistų sąveika.

\section{IVADAS}

2019 m. gruodžio mėnesị Kinijoje (Uhano mieste, Hubèjaus provincijoje), stebėtas neaiškios kilmės pneumonijos protrūkis, žaibiškai išplitęs beveik visose pasaulio valstybėse. $2020 \mathrm{~m}$. kovo $11 \mathrm{~d}$. Pasaulio sveikatos organizacija (PSO) paskelbè pandemiją, žinomą kaip COVID-19, kurią sukèlè naujasis koronavirusas (SARS-CoV-2). Šiandien pasaulyje registruota daugiau kaip 5 milijonai susirgimo COVID-19 atvejų ir daugiau nei 335,5 tūkstančio mirčių. Nors didžioji dalis simptomų susijusi su kvėpavimo sistemos pažeidimu, kuris daliai pacientų komplikuojasi daugybiniu organų nepakankamumu [1], pasirodo vis daugiau straipsnių ir pranešimų apie sąsajas su neurologiniais simptomais ar ligomis. Kol kas tai - pavieniai ir daugiau aprašomojo pobūdžio atvejai, todèl jais remiantis COVID-19 patogenezinio ryšio su neurologinèmis ligomis dar negalima neginčijamai patvirtinti.

Ši pandemija pakeitè daugelio pasaulio valstybių kasdienę sveikatos apsaugos sistemų veiklą. Dalis stacionarų

\author{
Adresas: \\ Mantas Vaišvilas \\ El.paštas mantas.vaisvilas@santa.lt
}

pritaikyta COVID-19 užsikrètusiems gydyti, tačiau planinès paslaugos ir lėtinėmis ligomis sergančių pacientų priežiūra tapo gerokai apribotos. Dėl to ieškoma telemedicinos sprendimų, kuriais būtų užtikrinta nenutrūkstama planinių paslaugų veikla ir lètinèmis ligomis sergančių pacientų priežiūra.

Šiame straipsnyje pristatome publikuotus duomenis apie traukulius, sergant COVID-19, ir pateikiame simptominių traukulių, epilepsinės būklès gydymo gaires sergantiems COVID-19. Taip pat pateikiame epilepsija sergančiu asmenų gydymo ir priežiūros rekomendacijas pandemijos metu, apžvelgiame telemedicinos galimybes ir trūkumus.

\section{COVID-19 IR SIMPTOMINIAI TRAUKULIAI}

Aprašyti pavieniai simptominių traukulių atvejai sergantiems COVID-19. Trumpa šių straipsnių apžvalga pateikiama 1 lentelèje [2-6]. Turimą informaciją reikètų vertinti kritiškai. SARS-CoV-2 sukeliamų neurologinių simptomų spektrui vertinti atliktoje sisteminèje analizėje pabrèžiama, kad kol kas didžioji dalis turimos informacijos yra iš atvejų aprašymų. Taip pat, didžioji dalis traukulių diagnozuoti kliniškai, traukulių fenotipas aprašytas labai abst-

(C) Neurologijos seminarai, 2020. Open Access. This article is distributed under the terms of the Creative Commons Attribution 4.0 International License CC-BY 4.0 (http://creativecommons.org/licenses/by/4.0/), which permits unrestricted use, distribution, and reproduction in any medium, provided you give appropriate credit to the original author(s) and the source, provide a link to the Creative Commons license, and indicate if changes were made. 
Epilepsija ir COVID-19: neurologo, paciento ir nacionalinès sveikatos sistemos iššūkiai pandemijos metu

1 lentelè. Straipsnių apie simptominius traukulius, sergant SARS-CoV-2, santrauka

\begin{tabular}{|c|c|c|c|c|c|c|c|}
\hline Autorius & $\begin{array}{l}\text { Priepuolius paty- } \\
\text { ré / visi tiriamieji }\end{array}$ & \begin{tabular}{|l} 
Straipsnio \\
tipas
\end{tabular} & $\begin{array}{l}\text { Vyraujantis klini- } \\
\text { kinis sindromas }\end{array}$ & EEG & Priepuoliai & Gydymas & Išeitis \\
\hline $\begin{array}{l}\text { Moriguchi } \\
\text { ir kt. [2] }\end{array}$ & $1 / 1$ & $\begin{array}{l}\text { atvejo } \\
\text { aprašymas }\end{array}$ & $\begin{array}{l}\text { SARS-CoV-2 } \\
\text { sukeltas meningo- } \\
\text { encefalitas }\end{array}$ & neatlikta & \begin{tabular}{|l|} 
vienas GTKT \\
priepuolis
\end{tabular} & $\mathrm{i} / \mathrm{v}$ LEV & neaprašyta \\
\hline $\begin{array}{l}\text { Karimi ir kt. } \\
{[3]}\end{array}$ & $1 / 1$ & \begin{tabular}{|l} 
atvejo \\
aprašymas
\end{tabular} & $\begin{array}{l}\text { SARS-CoV-2 } \\
\text { pneumonija }\end{array}$ & neatlikta & $\begin{array}{l}\text { kartotiniai } \\
\text { GTKT }\end{array}$ & $\begin{array}{l}\text { i/v LEV, } \\
\text { PHT }\end{array}$ & $\begin{array}{l}\text { priepuoliai } \\
\text { nesikartojo }\end{array}$ \\
\hline $\begin{array}{l}\text { Zanin ir kt. } \\
\text { [4] }\end{array}$ & $1 / 1$ & $\begin{array}{l}\text { atvejo } \\
\text { aprašymas }\end{array}$ & $\begin{array}{l}\text { SARS-CoV-2 sukel- } \\
\text { ti demielinizaciniai } \\
\text { židiniai, pneumonija }\end{array}$ & $\begin{array}{l}\text { epilepsinis akty- } \\
\text { vumas abipus } \\
\text { frontotemporaliai }\end{array}$ & GTKT & \begin{tabular}{|l|} 
LCM, \\
LEV, PHT
\end{tabular} & $\begin{array}{l}\text { priepuoliai } \\
\text { nesikartojo }\end{array}$ \\
\hline $\begin{array}{l}\text { Mao ir kt. } \\
\text { [5] }\end{array}$ & $1 / 214$ & $\begin{array}{l}\text { retrospektyvinè } \\
\text { analizė }\end{array}$ & $\begin{array}{l}\text { SARS-CoV-2 } \\
\text { pneumonija }\end{array}$ & neatlikta & GTKT & neaprašytas & neaprašyta \\
\hline Tan ir kt. [6] & $1 / 11$ & $\begin{array}{l}\text { retrospektyvinè } \\
\text { analizė }\end{array}$ & $\begin{array}{l}\text { SARS-CoV-2 } \\
\text { pneumonija }\end{array}$ & neatlikta & $\begin{array}{l}\text { febriliniai } \\
\text { traukuliai }\end{array}$ & neaprašytas & neaprašyta \\
\hline
\end{tabular}

EEG - elektroencefalograma; GTKT - generalizuoti toniniai-kloniniai traukuliai; i/v - į veną; LEV - levetiracetamas; PHT - fenitoinas; LCM - lakozamidas; VPA - valproinė rūgštis

rakčiai, daugumai pacientų nebuvo atliktas EEG tyrimas. Didelè dalis pacientų buvo kritiškai sunkios būklès, taigi traukulius galëjo sukelti hipoksemija, elektrolitų disbalansas ir kiti veiksniai [7]. Kinijoje atlikto retrospektyvinio tyrimo duomenimis, ištyrus 300 pacientų, sirgusių SARS-CoV-2, simptominių traukulių stebèta nebuvo [8].

Galima COVID-19 sąsaja su epilepsija minima dviejose publikacijose $[9,10]$. Pirmoje aprašoma pacientè, serganti gerai kontroliuojama (remisija - 2 metai) struktūrine epilepsija po persirgto herpetinio encefalito, kuriai, susirgus COVID-19, išsivystė židininè epilepsinė būklè. Pacientè vaistus nuo epilepsijos (VNE) vartojo reguliariai, prasidèjus traukulinei būklei nekarščiavo, kraujo tyrimais elektrolitų disbalanso ar kitų metabolinių sutrikimų nenustatyta. Galvos smegenų vaizdiniuose tyrimuose (KT ir MRT) ūmių pakitimų nestebėta. Kupiravus epilepsinę būklę ir paskyrus priešvirusinic gydymą, traukuliai daugiau nesikartojo, o paciente išrašyta ị namus gavus du neigiamus SARS-CoV-2 testų iš nosiaryklès atsakymus. Kadangi likvoro tyrimai neatlikti, negalima atmesti neuroinfekcijos galimybès, tačiau koronaviruso infekcija galèjo būti provokaciniu veiksniu traukuliams [9].

Antroji publikacija pateikia retrospektyvinę 22 atvejų analizę. Sergantiems COVID-19 pacientams dèl atsiradusios encefalopatijos ar traukulių atliktose EEG fiksuotas sporadinis epilepsiforminis aktyvumas frontalinėse srityse [10]. Tačiau šiame tyrime panašūs EEG radiniai stebèti ir daliai pacientų, nesergančių COVID-19, todèl radinių vertè nèra aiški.

\section{SIMPTOMINIŲ TRAUKULIŲ GYDYMAS}

Iprastai pacientams, patyrusiems ūminius simptominius traukulius, ilgalaikis gydymas VNE neskiriamas [11]. Tačiau COVID-19 sergantiems pacientams laikotarpis nuo simptomų atsiradimo iki išeities gali užtrukti nuo 6 iki 41 dienos [12]. Jei traukuliai kartojasi, rekomenduojamas gydymas VNE. Renkantis vaistą, būtina atsižvelgti ị vaisto ypatumus (veikimo pradžią, sąveiką su kitais vaistais, šalutinị poveiki) ir paciento būklę (amžių, kvèpavimo, inkstų, kepenų ir širdies funkciją) [13]. Skiriant hidroksichlorokviną pacientui, sergančiam epilepsija, kuris vartoja lakozamidą, būtina stebèti pakitimus elektrokardiogramoje. Širdies laidumo sutrikimus (QT intervalo pailgejjimą EKG) gali sukelti azitromicinas ir chlorokvinas, taip pat kai kurie VNE (pvz., karbamazepinas, lakozamidas, fenitoinas ir rufinamidas). Todèl, skiriant šiuos vaistus kartu, būtina stebėti EKG $[14,15]$. Informacija apie VNE sąveiką su priešvirusiniais vaistais pateikiama nuolat atnaujinamame Liverpulio vaistų sąveikos grupės, Bazelio (Šveicarija) ir Radboudo (Nyderlandai) universitetinių ligoninių tinklalapyje www.covid19-druginteractions.org. VNE sąveika su priešvirusiniais vaistais pateikiama 2 lentelèje [16].

Paskyrus VNE, gydymą rekomenduojama tęsti maždaug 6 savaites ir po to nutraukti per 1-2 savaites, palaipsniui mažinant doze.

Kadangi COVID-19 neretai prasideda aukšta temperatūra, kuri tęsiasi kelias dienas, o kai kuriems asmenims karščiavimas sukelia traukulius, rekomenduojami antipiretikai. Neseniai vyko aštrios diskusijos dèl galimo neigiamo ibuprofeno poveikio sergant COVID-19, tačiau balandžio mėnesio pabaigoje NIH (angl. National Institutes of Health) ir NICE (angl. National Institute for Health and Care Excellence ) paskelbė, kad nèra skirtumo tarp nesteroidinių vaistų ir paracetamolio poveikio, mažinant karščiavimą COVID-19 sergantiems ir nesergantiems pacientams, ir rekomenduoja pacientams, vartojusiems nesteroidinius priešuždegiminius vaistus, tęsti juos tomis pačiomis dozėmis, kokias vartojo anksčiau [17, 18].

\section{SIMPTOMINE் EPILEPSINE் BŪKLE் IR JOS GYDYMAS}

Ne visada simptominiai traukuliai pasireiškia aiškiais galūnių trūkčiojimais - galimi subtilūs raumenų trūktelèjimai ar tiesiog sąmonès sutrikimas [19]. Todèl, konsultuo- 
2 lentelè. VNE ir priešvirusinių vaistų sąveika [14]

\begin{tabular}{|c|c|c|c|c|c|c|c|c|c|c|c|c|}
\hline & ATV & DRV/c & $\mathbf{L P V} / \mathbf{r}$ & RDV & FAVI & CLQ & HCLQ & NITA & RBV & TCZ & INF $\beta$ & OSV \\
\hline CBZ & +++++ & +++++ & ----- & +++++ & & +++++ & +++++ & & & ----- & ----- & \\
\hline CZP & ----- & ----- & ----- & & & & & & & & & \\
\hline DZP & & & ----- & & & & & & & & & \\
\hline PHT & +++++ & +++++ & ----- & +++++ & & +++++ & +++++ & ----- & & ----- & ----- & \\
\hline PB & +++++ & +++++ & ----- & +++++ & & +++++ & +++++ & & & ----- & ----- & \\
\hline \multicolumn{13}{|l|}{ GBP } \\
\hline LCM & ----- & ----- & ----- & & & & & & & & & \\
\hline LTG & & ----- & ----- & & & & & & & & & \\
\hline \multicolumn{13}{|l|}{ LEV } \\
\hline \multicolumn{13}{|l|}{ LZP } \\
\hline OXC & ----- & ----- & ----- & ----- & & ----- & ----- & & & & ----- & \\
\hline \multicolumn{13}{|l|}{ PGB } \\
\hline TPM & & ----- & & & & & & & & & & \\
\hline VPA & & ----- & ----- & & & & & & & & ----- & \\
\hline
\end{tabular}

CBZ - karbamazepinas; CZP - klonazepamas; DZP - diazepamas; PHT - fenitoinas; PB - fenobarbitalis; GBP - gabapentinas; LCM lakozamidas; LTG - lamotriginas; LEV - levetiracetamas; LZP - lorazepamas; OXC - okskarbazepinas; PGB - pregabalinas; TPM topiramatas; VPA - valproinė rūgštis; ATV - azatanaviras; DRV/c - duranaviras/kobicistatas; LPV/r - lopinaviras/ritonaviras; RDV remdesiviras; FAVI - favipiraviras; CLQ - chlorokvinas; HCLQ - hidroksichlorokvinas; NITA - nitazoksanidas; RBV - ribavirinas; TCZ - tocilizumabas; INF $\beta$ - interferonas beta; OSV - oseltamiviras

\begin{tabular}{||c|l||}
\hline & Nėra sąveikos \\
\hline----- & Galima sąveika. Stebėti dèl sąveikos, skiriant kartu. \\
\hline+++++ & Stipri sąveika. Skirti kartu negalima. \\
\hline \hline
\end{tabular}

jant kritinès būklès pacientą, reikètų nepamiršti netraukulinès būklès tikimybės [20, 21]. Pastaroji diagnozuojama vadovaujantis visuotinai priimtais Zalcburgo netraukulinès būklès diagnostiniais kriterijais [22]. Jei pacientui, sergančiam COVID-19, pasireiškia klinikinis ar subklinikinis priepuolis, rekomenduojama nedelsiant pradėti gydymą [23].

Jeigu traukulių epizodas - vienintelis ir trunka iki 5 minučių, benzodiazepinų skirti nerekomenduojama. Pasikartojantiems priepuoliams arba epilepsinei būklei valdyti taikomi bendri epilepsinès būklès gydymo principai [13, 21, 24]. Pirmo pasirinkimo vaistai epilepsinei būklei gydyti išlieka benzodiazepinai, kuriuos skiriant gali pablogèti kvèpavimo funkcija (dažniausiai jau būna sutrikusi). Užsitęsus traukuliams, reikia pradèti gydymą vaistais nuo epilepsijos (VNE), kurie kritinès būklès pacientams skiriami intravenine forma. Dèl kvėpavimo ir kardiovaskulinės funkcijos pažeidimo geriau vengti vaistų, pasižyminčių poveikiu širdies ir kvėpavimo sistemai (fenitoino, fenobarbitalio), taip pat tų, kurie gali turèti reikšmingą farmakokinetinę sąveiką su kitais vaistais (karbamazepino, valproinės rūgšties) [13]. Be to, ekstrakorporinė membraninè oksigenacija, taikoma itin sunkios pneumonijos atvejais [25], gali lemti dideliu susirišimu su kraujo plazmos baltymais pasižyminčių VNE (fenitoino, valproinès rūgšties) farmakokinetiką [13]. Lakozamido reikètų vengti skirti pacientams, turintiems širdies laidumo sutrikimų (pvz., išreikšta pirmo laipsnio, antro laipsnio ar didesnè AV blokada), sergantiems širdies nepakankamumu ar esant miokardo išemijai, taip pat neskirti su vaistais, ilginančiais PR intervalą [26] Lakozamido taip pat nerekomenduojama skirti pacientams, kuriems yra sunkus kepenų funkcijos sutrikimas [24]. Sunkia COVID-19 infekcija sergantiems pacientams saugu skirti brivaracetamą. Esant sutrikusiai kepenų funkcijai, rekomenduojama skirti mažesnę dozę [27]. Levetiracetamas tinka visų tipų priepuoliams valdyti. Jis neturi sąveikos su kitais vaistais ir beveik nesukelia šalutinių reiškinių. Pacientams, kurių inkstų funkcija - sutrikusi, levetiracetamas skiriamas mažesne nei įprasta doze.

Pagrindinès epilepsinès būklès gydymo pandemijos metu rekomendacijos:

- vengti sedacijos ir intubacijos,

- skirti VNE kombinacijas,

- židininès epilepsinès būklès gydymui skirti benzodiazepinus arba antros eilès VNE (pagal epilepsinès būklès algoritmą) [28].

Rekomenduojama užtikrinti skubios medicinos gydytojų ir greitosios medicinos pagalbos darbuotojų švietimą apie psichogeninius neepilepsinius priepuolius, jų diagnostiką. Šie priepuoliai pasireiškia iki pusés dèl epilepsinės būklès gydomų asmenų. Jų atpažinimas leistų išvengti nereikalingos hospitalizacijos, intubacijos ir kitų netikslingų medicininių intervencijų. Apmokyti greitosios medicinos pagalbos personalą efektyviai teikti pagalbą traukulinès būklès pacientams. Naudojantis telemedicinos, e. sveikatos ir kitomis priemonėmis, užtikrinti pirmos eilès epilepsinei būklei gydyti reikalingų vaistų rezervą epilepsija sergantiems ir juos prižiūrintiems asmenims [28]. Sprendi- 
mas gydyti intensyviosios terapijos skyriuje turètų būti multidisciplininis, esant nepalankiai prognozei, ankstyva paliatyvi pagalba neturètų būti atidèliojama. Prognozei vertinti rekomenduojama naudoti ịvairias prognostines skales (Epidemiology-based mortality score in status epileticus (ESME) arba Status Epilepticus Severity Score (STESS) [29, 30].

\section{SERGANČIUUJŲ EPILEPSIJA PRIEŽIŪRA PANDEMIJOS METU}

Nėra patikimų duomenų, leidžiančių teigti, kad sergantieji epilepsija yra imlesni koronaviruso infekcijai ar serga sunkesne jos forma. Sunkesnès ligos formos rizikos veiksniai yra arterinė hipertenzija, cukrinis diabetas, lėtinės plaučiu ar kitų organų sistemų ligos ir vyresnis amžius $[1,5]$. Reikètų atkreipti dėmesị, kad kai kurie koronaviruso infekcijos simptomai, pavyzdžiui, karščiavimas, gali pabloginti ilgalaikę priepuolių kontrolę sergantiesiems Dravet sindromu ar kitomis epilepsijos formomis, tačiau publikuotos informacijos apie tai kol kas nèra. Nèra ir informacijos, kad naujasis koronavirusas didintų SUDEP (angl. sudden unexplained death in epilepsy patients) riziką [31, 32].

Vienas iš potencialių rizikos veiksnių optimaliai ligos kontrolei epilepsija sergantiems asmenims - psichologiniai faktoriai ir planinių sveikatos paslaugų prieinamumas pandemijos metu. Taivane SARS protrūkio metu $2003 \mathrm{~m}$. atliktas tyrimas, kuriame dalyvavo 227 epilepsija sergantys pacientai, parodè, kad $22 \%$ žmonių negavo vaistų dèl prarasto ryšio su sveikatos priežiūros paslaugų teikẻjais; $12 \%$ pacientų infekcijos protrūkio metu pablogejo priepuolių kontrolè, o dviem pacientams išsivystè epilepsinè būklè. Didžioji dalis pacientų sirgo vaistams rezistentiška epilepsijos forma [33]. Ne išimtis ir COVID-19: Kinijoje atliktas tyrimas parodė, kad gydymui vaistais atsparūs pacientai dèl pandemijos patiria daugiau psichologinès ir emocinès ịtampos, daug daugiau dèmesio kreipia ị žiniasklaidos pranešimus apie pandemijos mastą ir aukų skaičių. Psichologinis pažeidžiamumas ir kartais nepagrịsta šių pacientų panika gali lemti VNE vartojimo režimo pažeidimą, blogesnę ligos kontrolę ir su tuo susijusius dažnesnius apsilankymus gydymo įstaigose, taip didèjant užsikrètimo SARS-CoV-2 rizikai [34].

\section{REKOMENDACIJOS EPILEPSIJA SERGANTIEMS ASMENIMS PANDEMIJOS METU}

Tarptautinė lyga prieš epilepsiją (ILAE) ir Europos retu epilepsijų tinklo ekspertai epilepsija sergantiems pacientams pateikia šias rekomendacijas [35, 36]:

1. Nenutraukti VNE, nepasitarus su suaugusiujų arba vaikų neurologu.

2. Siekiant išvengti užsikrètimo, pacientams ir jų šeimos nariams vengti lankymosi ligoninès prièmimo skyriu- je ir atidèti vizitus pas specialistus, o iškilus medicininiams klausimams, skambinti savo šeimos gydytojui ar epilepsijos specialistui.

3. Jeigu epilepsijai gydyti paskirti vaistai, veikiantys imuninę sistemą (pvz., AKTH, steroidai, imunoterapija), tai gali padidinti riziką sirgti sunkesne COVID-19 infekcijos forma, tačiau šių vaistų vartojimo reikètų nenutraukti.

4. Jeigu epilepsijos priepuolis užsitęsia ilgiau nei iprastai (pvz., toniniams-kloniniams traukuliams užtrukus 2-3 minutes), skambinti greitosios pagalbos tarnybai, o pasikeitus traukulių pobūdžiui, rekomenduojama juos nufilmuoti ir paprašyti nuotolinès specialisto konsultacijos.

5. Kiekvienas pacientas privalo turèti vartojamų VNE sąrašą (jame turi būti nurodyta, kokiomis dozėmis ir kaip vartojate vaistus) ir, konsultuojantis su gydytoju, visada informuoti apie visus vartojamus vaistus.

6. Nerekomenduojama laukti, kol pasibaigs paskutinė VNE pakuotė prieš papildant atsargas, tačiau nereikia kaupti vaistų dideliais kiekiais.

7. Vaistus vartoti, kaip paskirta gydytojo, ir nepraleisti dozių.

8. Laikytis sveikos gyvensenos principų, vengti priepuolius sukeliančių veiksnių, kaip, pvz., miego trūkumas.

9. Jei VNE dozè buvo mažinama, pandemijos metu tai reikètų atidèti ir susisiekti su epilepsijos specialistu dèl tolimesnių gydymo rekomendacijų.

10. Gyvenantys vieni bent keletą kartų per dieną turètų susisiekti su šeimos nariais, draugais ar kaimynais.

11. Sergantys depresija ar nerimo sutrikimais, esant reikalui, turètų kreiptis pagalbos ị epilepsijos specialistą, psichologą ar psichiatrą.

12. Vaikams, vartojantiems metilfenidatą dèl aktyvumo ir dèmesio sutrikimo, gydymas turètų būti tęsiamas ir karantino metu.

13. Vaistams rezistentiškomis formomis sergantiems, kurie iki pandemijos buvo potencialūs kandidatai chirurginiam epilepsijos gydymui, galioja tie patys savisaugos ir gydymo principai. Kadangi tiek atranka epilepsijos chirurgijai, tiek pacientų priežiūra prieš ir po procedūros reikalauja išteklių, kurie pandemijos metu gali būti neprieinami, epilepsijos chirurgija, net ir komplikuotais atvejais, neturètų būti urgentine procedūra [37].

\section{REKOMENDACIJOS EEG TYRIMUI}

Kitas svarbus aspektas - užtikrinti saugią aplinką technologams ir pacientams atliekant EEG. Amerikos klinikinės neurofiziologijos draugija siūlo taikyti šias priemones [38]:

- Pacientai ir personalas turi dèvèti apsauginius akinius arba skydus, N95 respiratorius (jeigu nèra galimybès, medicinines kaukes) viso tyrimo metu.

- Riboti artimųjų buvimą procedūros metu iki vieno asmens. Lydintis asmuo privalo dèvèti apsaugos priemones. 
- Užtikrinti reguliarią pacientų ir personalo patikrą dèl COVID-19 simptomų: kasdien stebėti temperatūrą, tikrinti pacientus dèl infekcijos PGR metodu prieš hospitalizaciją ar procedūrą.

- Hiperventiliacija vertinama kaip aeorozolius generuojanti procedūra, todèl turètų būti atliekama tik tikintis vertingos diagnostinès informacijos.

- Ilgalaikis EEG monitoravimas turètų būti atliekamas tik urgentinių būklių diagnostikai. Ilgalaikio monitoravimo metu, siekiant sumažinti galimų kontaktinių asmenų skaičių, tyrimą turètų prižiūrèti tik vienas technologas arba, jeigu tai neịmanoma, - kuo mažesnis skaičius asmenų.

- Po kiekvieno tyrimo monitoravimo įranga privalo būti valoma dezinfekcinėmis priemonèmis.

- Monitoravimo įranga turètų būti uždengta plastikiniais apvalkalais. Jeigu ịmanoma, įranga turètų būti kitoje patalpoje nei pacientas. Esant galimybei, tyrimui naudoti vienkartinius elektrodus.

\section{TELEMEDICINA PANDEMIJOS METU}

Informaciją apie internetines ligonines ir telemedicinos paslaugų efektyvumą pristatė Kinijos Liaudies Respubli$\mathrm{ka}$, šios pandemijos metu ịrodžiusi, kad jos padeda valdyti pacientų srautą ligoninėse, dèl to mažèja užsikrètusiųu skaičius [39]. Epilepsijos srityje dar iki pandemijos buvo siūloma nemažai telemedicinos sprendimų: nuo telefoninių konsultacijų iki teleelektroencefalografijų, nuotolinių priepuolių aptikimo programų. Ankstesniais tyrimais įrodyta, kad telemedicina pagerina specializuotą priežiūrą, ypač atokiau gyvenantiems epilepsija sergantiems asmenims [40]. COVID-19 protrūkio Ispanijoje metu nuotolinès konsultacijos ir elektroninis receptas padejjo daliai epilepsija sergančių asmenų išvengti nereikalingų vizitų ị gydymo įstaigas [41]. Publikacijų apie kitokių priemonių naudojimą - teleelektroencefalografijų, nuotolinių priepuolių aptikimo programų pandemijos sąlygomis šiuo metu nėra [42]. Italija - viena iš šalių, telemedicinos klausimu pateikusi neigiamą patirtị. Omboni S. publikuotame straipsnyje nurodoma, kad dèl teisès aktų bazès, nepakankamo sveikatos sistemos finansavimo ir valdančiujų pavèluotų veiksmų šalyje pandemijos metu efektyviau veikė mobiliosios programėles kontaktiniams asmenims sekti, lyginant su telemedicinos paslaugomis, kurių plètra buvo atidèliojama daugeli metų [43]. Siektinas pavyzdys telemedicinos klausimu yra Jungtinès Amerikos Valstijos. Jau iki pandemijos teikusi nuotolines ūmaus insulto konsultacijas, JAV sveikatos sistema sẻkmingai taiko telemediciną ir epilepsijos srityje. Niujorko epilepsijos centro duomenimis, naudojant dabartinę ịrangą, galima atlikti iki $99 \%$ telekonsultacijų [44]. Koronaviruso pandemijos metu JAV atlikto tyrimo duomenimis, neurologinè teleapžiūra yra gana specifiška visiems radiniams, išskyrus patologinių refleksų patikrą [45]. Sèkmingos telemedicinos plètrą JAV lemia geras visuomenės kompiuterinis raštingumas, platus mobilių technologijų prieinamumas ir unifikuota elektroninès sveikatos sistema. Tai iliustruoja tyrimas, rodantis didẻjantị visuomenès susidoméjimą ir augantị telemedicinos paslaugų skaičių, daugėjant sergančiųjų skaičiui šalyje [46].

Šalims, kurių nacionalinėje sveikatos priežiūros sistemoje nėra integruotos telemedicinos, COVID-19 pandemija yra puikus metas įdiegti reikiamas reguliavimo sistemas, kad būtų pradèta plačiai taikyti telemedicina [47].

Galima pasidžiaugti, kad Lietuvoje pandemijos metu tapo galimos epilepsija sergančiǔjų asmenų telekonsultacijos ir bekontaktis receptų išrašymas, naudojantis „Elektroninės sveikatos“ sistema. Džiaugiamės ir tuo, kad, naudojant šias priemones nuo pandemijos pradžios Lietuvos Respublikoje, mūsų centre - Vilniaus universiteto ligoninèje Santaros klinikose - gydomi pacientai ị stacionarą nepateko ir yra stabilios būklès.

Vis dèlto, Lietuva yra viena iš šaliu, kuri nuo pandemijos nukentėjo nesmarkiai. Galbūt tai yra vienas iš veiksnių, nulèmusių stabilią lètinėmis ligomis sergančių pacientų būklę. Tokiose šalyse, kaip JAV ar Italija, kur sveikatos apsaugos sistemos ir telemedicinos galimybès yra gerokai pažangesnès, dèl didelio aukų nuo COVID-19 skaičiaus turimi vadinamieji teleištekliai tapo nepakankami $[43,46]$. Užtikrinti kokybiškų nuotolinių paslaugų nepavyko ir SARS metu [33].

Užklupusi pandemija pateikė sveikatos sistemai daug vertingų pamokų: kaip greičiau ir efektyviau reorganizuoti sveikatos įstaigų ir sveikatos apsaugos sistemos darbą ir išteklius, kaip leisti teises ir laisves apribojančius draudimo paketus, galiausiai, kaip neieškoti kaltininkų dèl esamos situacijos, toliau draudžiant ir baudžiant gydytoją kartu su pacientu, o spręsti iškilusias problemas. Galbūt šiandien išmoktos pamokos paskatins inovatyvius, ị sveikatos specialistus ir pacientą orientuotus tiesioginio ir nuotolinio konsultavimo bei gydymo sprendimus, padésiančius kovoti su nauja pandemija.

\section{APIBENDRINIMAS}

Nors publikuojama vis daugiau COVID-19 atvejų, pasireiškiančių traukuliais, patikimo ryšio tarp koronaviruso infekcijos ir epilepsijos nėra. Vaistų sąveika yra potencialus iššūkis epileptologams ir sergantiesiems epilepsija. Kuriami urgentinių neurologinių būklių ištyrimo ir gydymo protokolai, siekiant optimizuoti stacionarų išteklius pandemijos metu. Ieškoma telemedicinos sprendimų, norint užtikrinti nenutrūkstamą pagalbą sergantiesiems epilepsija. Nepaisant daugelio siūlomų sprendimų, kokybiškas nuotolinių paslaugų teikimas išlieka ribotas daugelyje pandemijos paveiktų valstybių. Siekiant išvengti ligų paūmẻjimų ir nereikalingų vizitu ị gydymo įstaigas, būtinas neurologų, pacientų, informacinių technologijų specialistų ir politikų bendradarbiavimas, kuriant telemedicinos sprendimus sergantiesiems lètinèmis ligomis. 


\section{Literatūra}

1. Zhu N, Zhang D, Wang W, Li X, Yang B, Song J, et al. A novel coronavirus from patients with pneumonia in China, 2019. N Engl J Med 2020; 382(8): 727-33. https://doi.org/ 10.1056/NEJMoa2001017

2. Moriguchi T, Harii N, Goto J, Harada D, Sugawara H, Takamino J, et al. A first case of meningitis/encephalitis associated with SARS-Coronavirus-2. Int J Infect Dis 2020; 94: 55-8. https://doi.org/10.1016/j.ijid.2020.03.062

3. Karimi N, Sharifi Razavi A, Rouhani N. Frequent convulsive seizures in an adult patient with COVID-19: a case report. Iran Red Crescent Med J 2020; 22(3): e 102828 https://doi.org/10.5812/ircmj.102828

4. Zanin L, Saraceno G, Panciani PP, Renisi G, Signorini L, Migliorati K, et al. SARS-CoV-2 can induce brain and spine demyelinating lesions. Acta Neurochir (Wien) 2020; 162: 1491-4. https://doi.org/10.1007/s00701-020-04374-x

5. Mao L, Jin H, Wang M, Hu Y, Chen S, He Q, et al. Neurologic manifestations of hospitalized patients with coronavirus disease 2019 in Wuhan, China. JAMA Neurol 2020; 77(6): 683-90. https://doi.org/10.1001/jamaneurol. 2020.1127

6. Tan X, Huang J, Zhao F, Zhou Y, Li JQ, Wang XY. [Clinical features of children with SARS-CoV-2 infection: an analysis of 13 cases from Changsha, China]. Zhongguo Dang Dai Er Ke Za Zhi 2020; 22(4): 294-8.

7. Asadi-Pooya AA, Simani L. Central nervous system manifestations of COVID-19: a systematic review. J Neurol Sci 2020; 413: 116832. https://doi.org/10.1016/j.jns. 2020.116832

8. Lu L, Xiong W, Liu D, Liu J, Yang D, Li N, et al. New onset acute symptomatic seizure and risk factors in coronavirus disease 2019: a retrospective multicenter study. Epilepsia 2020; 61(6): e49-53. https://doi.org/10.1111/epi.16524

9. Vollono C, Rollo E, Romozzi M, Frisullo G, Servidei S, Borghetti A, et al. Focal status epilepticus as unique clinical feature of COVID-19: A case report. Seizure 2020; 78: 109-12. https://doi.org/10.1016/j.seizure.2020.04.009

10. Galanopoulou AS, Ferastraoaru V, Correa DJ, Cherian K, Duberstein S, Gursky J, et al. EEG findings in acutely ill patients investigated for SARS-CoV2/COVID-19: a small case series preliminary report. Epilepsia Open 2020; 5(2): 314-24. https://doi.org/10.1002/epi4.12399

11. Bergey GK. Management of a first seizure. Continuum (Minneap Minn) 2016; 22(1 Epilepsy): 38-50 https://doi.org/10.1212/CON.0000000000000271

12. Rothan HA, Byrareddy SN. The epidemiology and pathogenesis of coronavirus disease (COVID-19) outbreak. J Autoimmun 2020; 109: 102433. https://doi.org/10.1016/ j.jaut.2020.102433

13. Farrokh S, Tahsili-Fahadan P, Ritzl EK, Lewin JJ, 3rd, Mirski MA. Antiepileptic drugs in critically ill patients. Crit Care 2018; 22(1): 153. https://doi.org/10.1186/s13054018-2066-1

14. Wu CI, Postema PG, Arbelo E, Behr ER, Bezzina CR, Napolitano C, et al. SARS-CoV-2, COVID-19, and inherited arrhythmia syndromes. Heart Rhythm 2020; 1-7. https://doi.org/10.1016/j.hrthm.2020.03.024

15. Auerbach DS, Biton Y, Polonsky B, McNitt S, Gross RA, Dirksen RT, et al. Risk of cardiac events in Long QT syndrome patients when taking antiseizure medications. Transl Res 2018; 191: P81-92.e7. https://doi.org/10.1016/j.trs1. 2017.10.002
16. International League Against Epilepsy. Clinically relevant Drug-Drug interaction between AEDs and medications used in the treatment of COVID-19 patients. 202003 25. Available from: https://www.lice.it/pdf/Antiepileptic_drugs_ interactions_in_COVID-19.pdf

17. Wehrwein P. Is the final word on ibuprofen and COVID-19 risk? 2020 [updated April 24, 2020]. Available from: https://www.managedhealthcareexecutive.com/news/ final-word-ibuprofen-and-covid-19-risk

18. World Health Organization. The use of non-steroidal anti-inflammatory drugs (NSAIDs) in patients with COVID-19. 2020 [updated 19 April 2020]. Available from: https://www.who.int/news-room/commentaries/detail/ the-use-of-non-steroidal-anti-inflammatory-drugs-(nsaids)in-patients-with-covid-19

19. Ch'ang J, Claassen J. Seizures in the critically ill. Handb Clin Neurol 2017; 141: 507-29. https://doi.org/10.1016/B9780-444-63599-0.00028-4

20. Manez Miro JU, Diaz de Teran FJ, Alonso Singer P, Aguilar-Amat Prior MJ. Emergency electroencephalogram: Usefulness in the diagnosis of nonconvulsive status epilepticus by the on-call neurologist. Neurologia 2018; 33(2): 71-7. https://doi.org/10.1016/j.nrleng.2016.05.007

21. Sutter R, Semmlack S, Kaplan PW. Nonconvulsive status epilepticus in adults - insights into the invisible. Nat Rev Neurol 2016; 12(5): 281-93. https://doi.org/10.1038/ nrneurol.2016.45

22. Leitinger M, Beniczky S, Rohracher A, Gardella E, Kalss G, Qerama E, et al. Salzburg consensus criteria for non-convulsive status epilepticus - approach to clinical application. Epilepsy Behav 2015; 49: 158-63. https://doi.org/10.1016/ j.yebeh.2015.05.007

23. Farrell JS, Colangeli R, Wolff MD, Wall AK, Phillips TJ, George A, et al. Postictal hypoperfusion/hypoxia provides the foundation for a unified theory of seizure-induced brain abnormalities and behavioral dysfunction. Epilepsia 2017; 58(9): 1493-501. https://doi.org/10.1111/epi.13827

24. Trinka E, Kalviainen R. 25 years of advances in the definition, classification and treatment of status epilepticus. Seizure 2017; 44: 65-73. https://doi.org/10.1016/j.seizure. 2016.11.001

25. Wang D, Hu B, Hu C, Zhu F, Liu X, Zhang J, et al. Clinical characteristics of 138 hospitalized patients with 2019 novel coronavirus-infected pneumonia in Wuhan, China. JAMA 2020; 323(11): 1061-9. https://doi.org/10.1001/jama. 2020.1585

26. Lachuer C, Corny J, Bezie Y, Ferchichi S, DurandGasselin B. complete atrioventricular block in an elderly patient treated with low-dose lacosamide. Cardiovasc Toxicol 2018; 18(6): 579-82. https://doi.org/10.1007/s12012018-9467-x

27. Brigo F, Lattanzi S, Nardone R, Trinka E. Intravenous brivaracetam in the treatment of status epilepticus: a systematic review. CNS Drugs 2019; 33(8): 771-81. https://doi.org/ 10.1007/s40263-019-00652-0

28. Kinney MO, Brigo F, Kaplan PW. Optimizing status epilepticus care during the COVID-19 pandemic. Epilepsy Behav 2020; 109: 107124. https://doi.org/10.1016/ j.yebeh.2020.107124

29. White DB, Lo B. A Framework for rationing ventilators and critical care beds during the COVID-19 pandemic. JAMA 2020; 323(18): 1773-4. https://doi.org/10.1001/jama. 2020.5046 
30. Yuan F, Gao Q, Jiang W. Prognostic scores in status epilepticus - a critical appraisal. Epilepsia 2018; 59(Suppl 2): 170-5. https://doi.org/10.1111/epi.14483

31. Kuroda N. Epilepsy and COVID-19: associations and important considerations. Epilepsy Behav 2020; 108: 107122. https://doi.org/10.1016/j.yebeh.2020.107122

32. French JA, Brodie MJ, Caraballo R, Devinsky O, Ding D, Jehi L, et al. Keeping people with epilepsy safe during the Covid-19 pandemic. Neurology 2020; 94(23): 1032-7. https://doi.org/10.1212/WNL.0000000000009632

33. Lai SL, Hsu MT, Chen SS. The impact of SARS on epilepsy: the experience of drug withdrawal in epileptic patients. Seizure 2005; 14(8): 557-61. https://doi.org/10.1016/j.seizure. 2005.08.010

34. Hao X, Zhou D, Li Z, Zeng G, Hao N, Li E, et al. Severe psychological distress among epilepsy patients during the COVID-19 outbreak in southwest China. Epilepsia 2020; 61(6): 1166-73. https://doi.org/10.1111/epi.16544

35. International League Against Epilepsy. COVID-19 and epilepsy. Available from: https://www.ilae.org/patient-care/ covid-19-and-epilepsy/\%20accessed $\% 20$ on $\% 20$ April $\%$ 2014,\%202020

36. European Reference Network for Epilepsy: European Reference Network for Epilepsy Steering Comitee. COVID-19 and Epilepsy - ERN EpiCARE Recommendations. Available from: https://epi-care.eu/covid-19-and-epilepsy-ernepicare-recommendations/

37. International League Against Epilepsy. Neuropsychological assessments for epilepsy surgery during COVID-19 restrictions. Available from: https://www.ilae.org/files/ dmfile/Neuropsychological-Assessments-for-EpilepsySurgery-.pdf

38. American Clinical Neurophysiology Society. COVID-19 resources for clinical neurophysiology [updated April 22, 2020]. Available from: https://www.acns.org/practice/ covid-19-resources

39. Gong K, Xu Z, Cai Z, Chen Y, Wang Z. Internet hospitals help prevent and control the epidemic of COVID-19 in China: multicenter user profiling study. J Med Internet Res 2020; 22(4): e18908. https://doi.org/10.2196/18908

40. Haddad N, Grant I, Eswaran H. Telemedicine for patients with epilepsy: a pilot experience. Epilepsy Behav 2015; 44: 1-4. https://doi.org/10.1016/j.yebeh.2014.11.033

41. Hernando-Requejo V, Huertas-González N, Lapeña Motilva J, Durán GO. The epilepsy unit during the COVID-19 epidemic: the role of telemedicine and the effects of confinement on patients with epilepsy. Neurologia 2020; 35(4): 274-6. https://doi.org/10.1016/j.nrleng.2020.04.012

42. Santos-Peyret A, Durón RM, Sebastián-Díaz MA, CrailMeléndez D, Goméz-Ventura S, Briceño-González E, et al. [E-health tools to overcome the gap in epilepsy care before, during and after COVID-19 pandemics]. Rev Neurol 2020; 70(9): 323-8. https://doi.org/10.33588/ rn.7009.2020173

43. Omboni S. Telemedicine during the COVID-19 in Italy: a missed opportunity? Telemed J E Health 2020. https://doi.org/10.1089/tmj.2020.0106

44. McNamara D. COVID-19: telemedicine gets real, real fast across neurology [updated March 28, 2020]. Available from: https://www.medscape.com/viewarticle/927714\#vp_3

45. Grossman SN, Han SC, Balcer LJ, Kurzweil A, Weinberg H, Galetta SL, et al. Rapid implementation of virtual neurology in response to the COVID-19 pandemic. Neurology 2020; 94(24): 1077-87. https://doi.org/10.1212/WNL. 0000000000009677

46. Hong YR, Lawrence J, Williams D, Jr., Mainous IA. Population-level interest and telehealth capacity of US hospitals in response to COVID-19: cross-sectional analysis of Google search and National Hospital survey data. JMIR Public Health Surveill 2020; 6(2): e18961. https://doi.org/10.2196/ 18961

47. Ohannessian R, Duong TA, Odone A. Global telemedicine implementation and integration within health systems to fight the COVID-19 pandemic: a call to action. JMIR Public Health Surveill 2020; 6(2): e18810. https://doi.org/10.2196/ 18810

\section{Vaišvilas, A. Jasionis, R. Mameniškienė}

\section{EPILEPSY AND COVID-19: CHALLENGES FOR THE NEUROLOGIST, PATIENT, AND NATIONAL HEALTH SYSTEM DURING A PANDEMIC}

\section{Summary}

Although COVID-19 is most often associated with respiratory symptoms and less frequent multiple organ failure, a variety of neurological symptoms is possible in infected individuals. Cases of COVID-19-induced seizures have been reported, although their association with epilepsy is questionable. When a person with epilepsy is infected with COVID-19 and treated with antiviral drugs, the interaction of these drugs with antiepileptic drugs used is important. The psychological condition of patients is an important factor in controlling seizures, and the pandemic changes the care of patients with chronic diseases. In this article, we provide a review of the literature on the treatment of symptomatic seizures and status epilepticus, and the care of people with epilepsy during the COVID-19 pandemic. We also present the latest recommendations for electroencephalography.

Keywords: epilepsy, seizures, COVID-19, SARS-CoV-2, telemedicine, drug interactions.

Gauta:

20200518

Priimta spaudai: 20200606 